\title{
Czytanie tekstów Jacka Brzozowskiego
}

Nie istniejemy bez pamięci. [...] Ona, pamięć, zakorzenia nas w materii świata. Jeśli prawdziwie b y ć znaczy być świadomie, zawdzięczamy to pamięci. Jeśli coś pozwala nam mieć poczucie tożsamości, to także właśnie pamięć. Bez wątpienia jest ona wielką życiodajną siłą. Ale potrafi być również zgubna. Potrafi być i jest zgubna, kiedy prowadzi do przyzwyczajenia. To znaczy, kiedy powoduje, że to, co jest nam dane - świat, rzeczywistość oraz my sami - wydaje się oczywiste i proste, na wskroś znane i oswojone. Kiedy - mówiąc inaczej - wszystko, co istnieje, traci głębsze znaczenie i tym samym przestaje dla nas istnieć naprawdę, tj. istnieć w swej wyjątkowości, niepowtarzalności i w ogóle w samym cudownym (= nieoczywistym) fakcie swego istnienia (Czesław Miłosz, "Sroczość", [w:] 11 szkiców o czytaniu wierszy, Łódź 2013, s. 16-17).

[...] topos jest podpowiadanym przez tradycję wzorem odpowiedzi na wyzwanie, jakie stawiają przed twórcą rzeczywistość bądź problemy związane z kształtowaniem dzieła. Część tego, co dla poety mieści się w pojęciu „rzeczywistość”, określają pytania, których nie może on - właśnie dlatego, że jest poetą - pomijać. Należą do pytań podstawowych, pierwszych. Są, jeśli wolno tak powiedzieć, egzystencjalnymi pytaniami wynikającymi z kulturowego faktu „bycia poetą". Brzmią prosto: Kim jestem ja, poeta? Kim jest poeta? Kto jest poetą? Czym jest poezja? Co stanowi jej sens, jej „istotę"? Dochodzą do tego pytania wiążące się z bardziej już konkretną problematyką - kształtowania dzieła: Czym jest ten poemat, ten wiersz? Jakie jest jego znaczenie, jego status? Jaką ma wartość? Jakie są jego źródła? Podobnych pytan, w różnych wariantach i subtelnych 
odmianach znaczeniowych, wyliczyć by można wiele. Nie zmieni to jednak prawdy, że zawsze odnosić się będą, w mniejszym czy większym stopniu, do „prób wyjaśnienia tego, co nie jest możliwe do wyjaśnienia"1.

Nie jest możliwe wyjaśnienie. Ale możliwe i konieczne jest podejmowanie prób wyjaśnienia. Albowiem tylko wtedy spełnia się - użyję potraktowanego ironicznie w zacytowanej uwadze słowa - istotą „bycia poetą”. Nie jest możliwe wyjaśnienie. Ale możliwa i konieczna jest, skoro pojawiają się pytania, odpowiedź. Odpowiedź, która nie zamyka w sobie - tak jak łupina orzech - wyjaśnienia, ale która jest, niczym gest, sama w sobie wyjaśnieniem (Muzy w poezji polskiej. Dzieje toposu do przełomu romantycznego, WrocławWarszawa-Kraków-Gdańsk-Łódź 1986, s. 28).

Opinie, lekcje i sądy poprzedników raczej więc tylko przypominam (zarazem dążąc $w$ tym do pełnego rejestru) niż oceniam czy polemizuję z nimi. Wypływa to z mojego głębokiego przekonania, że nie polemika, ale wysłuchanie wszystkich należących do rzeczy głosów tak, jak w swoim czasie i miejscu zostały wypowiedziane, jest najprostszym sposobem wytyczania kolejnych etapów tej drogi - wspólnej drogi - na której próbujemy przybliżyć się do „całej prawdy" o poezji Mickiewicza, prawdy wciąż nowej i nieodmiennie zdumiewającej (Od Autora, [w:] Odczytywanie znaczeń. Studia o poezji Mickiewicza, Łódź 1997, s. 6).

Romantyczność przynosiła poetyckie określenie nowego na świat i człowieka spojrzenia. Żeglarz, manifest romantycznego indywidualizmu, mówił o konsekwencjach i zarazem perspektywach, jakie rysowały się przed tym, kto wewnętrznie przekonany o prawdzie tego spojrzenia, zaufał mu i wiernie szedł jego śladem. W obu wierszach to, co nowe, dochodziło do głosu na drodze uczciwego i otwartego dialogu z postawami i wartościami, których Mickiewicz nie akceptował. Oba wiersze miały swoje szekspirowskie odniesienia. Oba postawił poeta w porównywalnych wzajem miejscach dwóch poetyckich części debiutanckiego tomu Poezji. Prosto i wymownie pokazał w ten sposób - jakby ponad osobnymi sensami każdego z wierszy - czym był naówczas w ogóle i czym dla niego był romantyzm jako pewna światopoglądowa i poetycka całość (Kształt „Romantyczności” (glosy do wiersza), [w:] Odczytywanie znaczeń. Studia o poezji Mickiewicza, Łódź 1997, s. 40).

${ }^{1}$ J. Sadzik, O Psalmach, [w:] Księga Psalmów, tłum. z hebrajskiego Cz. Miłosz, Paris 1979, s. 11. 
Już więc tu, na Krymie, o świtaniu, za dnia, w widoku miejsca najrozkoszniejszego, w sonetowej o tym opowieści - odkrył Mickiewiczowski pielgrzym, odkrył twórca tego pielgrzyma uniwersalne prawa rządzące skomplikowanym światem i życiem, egzystencją, losem, i dał temu wyraz od razu w pierwszym, entuzjastycznym i epifanicznym słowie Ałuszty w dzień. W lirykach lozańskich natomiast, trwając nadal przy tych prawach, przede wszystkim nie znalazł możliwości uzgodnienia ich z poezją. Odszedł więc od wierszy (O Atuszcie w dzień i krymskim cyklu, [w:] Odczytywanie znaczeń. Studia o poezji Mickiewicza, Łódź 1997, s. 81).

Pełnia człowieczeństwa bywa - na przekór okolicznościom i stereotypom, jak w przypadku Jankiela - darem: jest dana z natury. Bywa również - jak w przypadku Jacka - wyzwaniem i trudem: jest celem, do którego dochodzi się przez piekło własnej duszy i szatańskie labirynty historii. Jedna i druga mają wymiar wyjątkowej, najwyższej (romantycznej) duchowości. Ale jest także pełnia dnia codziennego, pełnia, w stronę której poszedł „młody panek", w stronę której pójść może każdy (Pan Tadeusz - bohater rzetelnie tytułowy, [w:] K. Poklewska, J. Brzozowski, O Mickiewiczu i Stowackim - cztery szkice, Łęczyca 1999, s. 19).

Spróbujmy - nieco demagogicznie - pomyśleć, że nie ma Tadeusza w Panu Tadeuszu. Nie powraca więc do domu ukochany synowiec Sędziego, Soplicowo nie będzie mieć dziedzica. Jacek umiera bezpotomnie - nie połączą się zwaśnione rody, a rozpoczęty przez ojca czyn polityczny nie znajdzie realizującego go spadkobiercy. Nieszczęsny kwestarz nie okaże też w pełni, jak bardzo się przemienił: nie będzie miał okazji, by w ostatniej godzinie zrezygnować ze sceny rozpoznania z synem. Znikną zawikłane sercowe kłopoty: Zosia wyjdzie za Saka; Telimena nie ujawni swoich łowieckich umiejętności, a i mrówek zapewne nie przynęci, bo i dla kogo? Majora Płuta również nikt w twarz nie trzaśnie, dając tym co prawda nie powód, ale znakomicie nieodwołalne hasło do rozprawy z Moskalami. Hrabia - o ile wcześniej nie dosięgnie go niedźwiedź - nie zobaczy godnej i męskiej postawy opuszczającego dom przyszłego ułana; i sam najpewniej nie wyjedzie, spleenując $\mathrm{w}$ ruinach zamku (Pan Tadeusz - bohater rzetelnie tytułowy, [w:] Odczytywanie romantyków, Kraków 2002, s. 74-75). 
Snuć miłość - jeden z liryków lozańskich. Prawdopodobne jednak, że również (a może i przede wszystkim) zapisane w Lozannie 1839 zdanie: budująca maksyma, obszerna, zatrzymana na granicy sonetu, starannie ukrywająca liryczne ,ja" (Pointa artykułu Trzy domysty na marginesie wiersza "Snuć mitość", „Prace Polonistyczne”, seria LVIII, 2003, s. 77).

[...] warunkiem sine qua non interpretacji wielu wierszy autora Beniowskiego musi być pełne rozpoznanie ich rękopiśmiennej otwartości i alternatywności, nieostateczności i brulionowości. Hermeneutyce i sztuce interpretacji musi tu towarzyszyć i musi współbrzmieć z nimi w sposób możliwie pełny, często też w proporcjach zdecydowanie przeważających, wszystko to, co składa się na rzemiosło edytora. Nie widzę innej drogi do Słowackiego-poety (Notatki do lektury wierszy, [w:] Parerga edytorskie (Z prac nad tekstami Juliusza Stowackiego), Łódź 2013, s. 52).

Edycja, o jakiej myślę, byłaby wydaniem zupełnym - zawierającym wszystkie znane teksty Słowackiego (w tym obcojęzyczne, wraz z nowymi ich przekładami): utwory literackie i pisma prozą, listy, plany utworów, informacje o utworach zaginionych bądź zniszczonych, utwory o autorstwie wątpliwym, wszelkiego rodzaju notatki, wypisy z innych dzieł oraz zapiski na ich marginesie, dedykacje, rachunki, pisma urzędowe, życiorysy, testamenty etc. Etc. Zawierałaby również podobizny rysunków i szkiców poety, bądź zachowanych w rękopisach, bądź zaginionych, ale wcześniej opublikowanych. W wielu wypadkach, jak choćby starannych akwarel w Album rysunkowym, szkicu pastereczki z Pornic w Raptularzu czy satyrycznych rysunków antymickiewiczowskich i antytowianistycznych, stanowią one istotną cząstkę twórczej aktywności poety. Owszem, nie są „pismami”. Znakomicie jednak z nimi współbrzmią, co „dzieł” zaś - z pewnością należą („Dawniej myślałem rzeczy uczynić szalone...". Kilka uwag o idei „Dzieł zebranych" Juliusza Stowackiego, [w:] Parerga edytorskie..., s. 6-7).

"Cierpieć, doznawać bólu, przeżywać strach - ale być po stronie życia, doświadczanego boleśnie, ale właśnie dlatego niezafałszowanego; być więc po stronie życia, po stronie strachu i cierpienia - przeciw dyktatorowi istniejącemu w bezgranicznej samotności fikcyjnego potiomkinowskiego świata władzy - to być, rzecz jasna przeciwko tyranii i zniewoleniu, ale przede wszystkim oznacza to być przeciwko samotności" (Z interpretacji Jesieni patriarchy 
Gabriela Garcíi Márqueza stanowiącej część eseju: G.G. Márquez, Sto lat samotności - maszynopis niedatowany; lata 80. XX wieku, tekst podkreślony ręką autora, s. 22).

To, czego się nauczył, cała świadomość, jaką posiada, głęboka i cenna - nie jest jeszcze żadnym zabezpieczeniem przeciwko utracie tożsamości. Jej istnienie uwarunkowane jest bowiem nie kończącym się nigdy formowaniem samego siebie. Co więcej, naprawdę zaczyna się ono dopiero po opuszczeniu domu rodzinnego i szkoły, w zderzeniu ze światem, w burzy i ciemności (,Pan Cogito" Zbigniewa Herberta, Warszawa 1991, s. 19).

Pan Cogito, poemat w czterdziestu fragmentach, wydaje się być - przy zachowaniu wszelkich proporcji - oryginalnym nawiązaniem do koncepcji literatury, która nie oszczędzając i świata, i bohatera, i czytelnika, prowadzi tego ostatniego, dla nauki, dojrzałości i ocalenia, przez piekło świata. I która, na koniec tej wędrówki, odnajduje i zapala światło. Mały krąg światła, który wedle światowych miar jest niczym. Ale który w istocie, płonąc jasno i pewnie, jak oczy Pana Cogito, wytycza trudną, lecz godną drogę przez morze ciemności. I w takim sensie, kończąc się Przestaniem..., kończąc się podniosłym epilogiem, poemat opowiadający historię Pana Cogito chce być książką nie tylko mądrą, ale i budującą. Jak Mickiewiczowska „,historia szlachecka", jak Vede-mecum Norwida... (Pan Cogito, [w:] Dlaczego Herbert. Wiersze - komentarze - interpretacje, wyd. II poszerzone, red. M. Woźniak-Łabieniec, J. Wiśniewski, Łódź 2004, s. 266-267).

[Szare eminencje Mirona Białoszewskiego] Są opowieścią o człowieku i wszechświecie, o poecie i jego kosmosie. Kosmosem, wszechświatem, całym światem jest dom, mieszkanie, pokój: najmniejsza, intymna przestrzeń wraz ze wszystkimi najzwyklejszymi przedmiotami, jakie ją zapełniają. Tylko w tej przestrzeni, pełnej własnego ładu i oswojonej, zamkniętej i gwarantującej całkowitą wolność jest szansa na to, ażeby „być" naprawdę: w centrum, w sobie i sobą. To "być" równoznaczne jest z esse, z udziałem we wszechbycie. I nie ma w tej poetyckiej opowieści o domu jako kosmosie mitologizowania. Jest natomiast poetyckie, metafizyczne poczucie prawdziwego istnienia, tożsamości, osobności i szczęścia, poczucie ugruntowane na sprawdzalnej realności powszednich, byle jakich rzeczy (Budujące zejście do sklepu, [w:] O wierszach Mirona Białoszewskiego. Szkice i interpretacje, oprac. naukowe i redakcyjne J. Brzozowski, Łódź 1993, s. 49). 
Na koniec tom Oho przynosi pełny obraz rozporoszonych wcześniej nastrojów i emocji: od narastającej niechęci do siebie "nieswojego", byle jakiego, cierpiącego, od narastającego zniecierpliwienia sobą, zniecierpliwienia koniecznością „bycia”, poprzez obojętność na wszystko, aż po pełne harmonii uspokojenie (Wypis VI) i nadzieje na spokój ostateczny (Wywiad). Nadzieję wyrażoną bez patosu i egzaltacji, bez huku i rozpaczy, w najzwyklejszej, codziennej, po trosze jakby też przypadkowej rozmowie ze śmiercią, rozmowie Mistrza Mirona ze śmiercią. [...] Tu, kiedy odbiera śmierci jej metafizyczny strach i umieszcza ją wpośród codziennych przedmiotów i wydarzeń, kiedy przekreśla jej bezsens i absurd stawiając ja w szeregu niepoliczonych rzeczy i zdarzeń, które składają się na dusze świata, kiedy zatem odbiera śmierci metafizyczną grozę, ale pozostawia metafizyczne znaczenie - spełnia poezja Białoszewskiego swoją ostatnią rolę. mianowicie do końca umożliwia „być sobie jednym”. Któż bowiem inny tak całkiem naturalnie nazwać by mógł rozmowę ze śmiercią wywiadem, a samą śmierć odfrunięciem w głąb ziemi. Odfrunięciem, chciałoby się wierzyć, na oglądanie owej duszy świata (O poezji Mirona Białoszewskiego, [w:] O wierszach Mirona Białoszewskiego..., s. 33-34).

Przynosi to ostatnie słowo - Wiersz ostatni - obraz tuż pośmiertnych losów monolog Wata-Orfeusza: Orfeusz schodzi pod ziemię i jednocześnie mówi podczas tego schodzenia - mówi o swoim schodzeniu, o swojej katabazie. [...]

Katabaza jest - dobitnie to wyraża już sama rzeczownikowość głównego w wierszu słowa - dalece odpodmiotowiona. Stychiczny, rzeczowy, "różewiczowski” tok wiersza oraz jego nieregularny rytm nadają schodzeniu piętno pośpieszności i niekończącej się monotonii. Jednocześnie jest ono, jest to „schodzenie”, zbiorowe i anonimowe. Ta zbiorowość i anonimowość nieustającej katabazy, nieustającego pochodu śmierci nie daje pocieszenia. Przeciwnie, odbiera całą należną tutaj powagę i doniosłość, niszczy poczucie wyjątkowości, osobności i prywatności. To, do czego Orfeusz przygotowywał się przez lata, przy pomina nie więcej, jak prozaiczną codzienność wielkomiejskiego tłumu na stacji ruchliwego metra. Tak jak gdyby w chwili, kiedy ostatecznie zapadła decyzja o odejściu, ów Orfeusz traci mistyczne złudzenia i tęsknoty, gubi swą - "orficką" - metafizykę i eschatologię, i tym samym otwiera się na nagą i pustą rzeczywistość ostatniej drogi. Otwiera się nie bez wahania, nie bez gorzkiego i po trosze ironicznego zdziwienia: „I gdzie ja się zapodziałem?". Otwiera - jeszcze nie wierząc, że tak wygląda jego zejście do Hadesu. A wygląda istotnie tylko tak. Więcej nawet niż "tylko tak". 
Okazuje się to i ostatecznie potwierdza zaraz dalej, kiedy zagubiony w tłumie bohater spotyka Eurydykę: „Eurydyce? Eurydyce!” Zapewne są w tym zapytaniu i wykrzyknieniu emocje rozpoznania. Lecz przede wszystkim jest potwierdzenie, że ten tłum, i ten pośpiech, i to, co dzieje się teraz z Orfeuszem, to jest naprawdę katabaza, schodzenie do krainy śmierci. [...] Przechodzi więc teraz ów Orfeusz mimo Eurydyki, stwierdzając nie więcej, jak tylko absurdalność katabazy: nieustanne i ciągle w dół zstępowanie kończy się zaledwie metr pod ziemią. Katabaza jest nie czym innym, jak wyłącznie zejściem do grobu, najdosłowniej zejściem do grobu. [...]

Na końcu swoich rozmów ze śmiercią, stając na jej progu, poeta wycofał się z budującego mitu. Można sądzić, że nie szukał wtedy pocieszenia i nie czynił ostatecznej decyzji łatwiejszą. Kiedy zaś pamiętać, że przeżywał swój los i egzystencję właśnie en poète, to wycofanie się - realistyczne wycofanie się - realistyczne wycofanie się Orfeusza w stronę „prozy śmierci” - okazuje swoją tym większą wagę (Aleksander Wat: „Wiersz ostatni”, [w:] Późne wiersze poetów polskich XX wieku. Dwanaście szkiców i komentarzy, Łódź 2007, s. 56-57).

Zapewne przesadą byłoby twierdzić, że cmentarze i groby stanowią centralne punkty na mapie peregrynacji Słowackiego. Z pewnością też nie one - wyjąwszy grób w Jerozolimie - wytyczały mu na tej mapie drogę. Kiedy je jednak na niej znajdował, nie przechodził mimo. Przeciwnie, przyciągały go i zatrzymywały.

Powodów tego było wiele; ponieważ jednak w miarę przekonujące ich wyliczenie zajęłoby grubo więcej niż pozwala zwięzły głos w dyskusji, odnotuję (nie bez demagogii) tylko dwie kwestie. Po pierwsze (i ogólne): rzecz o Słowackiego grobach i cmentarzach - od epizodu w Westminsterze do dumań przed posągiem Dantego we florenckim kościele - układałaby się w opowieść o człowieku, który od „światowych” marzeń i ambicji literata doszedł - nie rezygnując z nich - do pełni znamionującej Poetę. Owszem, nie byłaby to opowieść o Słowackim zasadniczo innym niż ten, którego znamy; tu i ówdzie jednak nowe czy mniej oczywiste akcenty pojawiałyby się na jego portrecie. Po drugie, niekiedy na dalekim tle, niekiedy wprost i bezpośrednio zawęźlały się te wejścia poety w przestrzeń cmentarza i grobu z myślą o własnym grobie, z myśleniem o własnym miejscu ostatecznego spoczynku (Szukanie grobu, [w:] Parerga edytorskie..., s. 89). 